Bangladesh Journal of Anatomy July 2011, Vol. 9 No. 2 pp 93-95

\title{
Distance Between the Base of Vermiform Appendix and Ileocaecal Junction: A Postmortem Study
}

\author{
Uttam Kumar Paul', ABM. Omar Faruque ${ }^{2}$, Md. Jahangir Alam³, Tahmina Begum4, Md. Belayet \\ Hossain Khan ${ }^{5}$, M.Tanveer Hossain Parash ${ }^{6}$
}

\begin{abstract}
Context: The human vermiform appendix is usually termed as "a vestigial organ". Currently available evidence suggests that the appendix is a highly specialized part of alimentary tract.

The vermiform appendix participates in the secretory immune system in the gut. Secretory immunoglobulins produced by the gut associated lymphoid tissue (GALT) act as a effective barrier. Appendix is affected by different disease processes such as appendicitis, carcinoma and diverticulitis. Appendicitis is the most common clinical condition. An appropriate anatomical knowledge about vermiform appendix is important for surgeons, pathologists and other physicians for proper diagnosis and management of diseased appendix.
\end{abstract}

Study design: Descriptive type of study.

Place and period of the study: Department of Anatomy, Sir Salimullah Medical College, Dhaka from January 2006 to June 2007.

Materials and Method: Sixty (60) human postmortem vermiform appendix, age ranging from 0 to 65 years. Fresh samples were collected from the morgue of Sir Salimullah Medical College and Dhaka Medical College, Dhaka. The samples were divided into five (5) different age groups.

Result: The distance between the base of the vermiform appendix and ileocaecal junction was not significant when compared among different age groups $(P>0.10$ or $P>0.50)$.

Key words: distance, base of the appendix, ileocaecal junction, vermiform appendix.

Introduction:

The vermiform appendix is a narrow, vermian (worm shaped) tube arising from the posteromedial caecal wall $2 \mathrm{~cm}$ or less below the ileocaecal junction ${ }^{1}$. It is suspended by mesoappendix. The breadth of the mesoappendix is usually short in respect to the length of the appendix. The anterior taenia is usually distinct and traceable to the base of the appendix ${ }^{1}$.

1. Assistant Professor, Department of Anatomy, Sir Salimullah Medical College, Dhaka

2. Associate Professor and Head, Department of Anatomy, Sapporo Dental College, Uttara, Dhaka

3. Assistant Professor, Department of Anatomy, Sir Salimullah Medical College, Dhaka

4. Lecturer, Department of Anatomy, Sir Salimullah Medical College, Dhaka

5. Assistant Professor and Head, Department of Forensic Medicine, Sir Salimullah Medical College, Dhaka

6. Assistant Profesor (c.c), Department of Anatomy, Satkhira Medical College.

Correspondence: Dr. Uttam Kumar Paul
The base of the appendix lies deep to a point that is one-third of way along the oblique line, joining the right anterior-superior iliac spine to the umbilicus ${ }^{2}$. This point is known as McBurney's or spinoumbilical point. lleum opens in the posteromedial caecal wall at its junction with the ascending colon. The ileocaecal junction corresponds with the intersection between the transtubercular and right lateral plane.

Distance between the appendix and ileocaecal junction provide information to general, paediatric and laparoscopic surgeons regarding location of appendix during surgical procedure ${ }^{3}$

\section{Materials:}

The present study was performed on sixty (60) human postmortem vermiform appendix of Bangladeshi people. The collected samples were divided into five age groups. The groups were GroupA (0-20 years), Group-B (21-30 years), Group-C (3140 years), Group-D (41-50 years) and Group-E (above 50 years) (Table $-\mathrm{I})$ 
Table-I

Age distribution of different groups (from Glover 1988) ${ }^{4}$

\begin{tabular}{lccc}
\hline Groups & $\begin{array}{c}\text { Age in } \\
\text { years }\end{array}$ & $\begin{array}{c}\text { Number of } \\
\text { samples }(\mathrm{n}=60)\end{array}$ & $\begin{array}{c}\text { Percentage } \\
(\%)\end{array}$ \\
\hline A & $0-20$ & 10 & 16.67 \\
B & $21-30$ & 17 & 28.33 \\
C & $31-40$ & 15 & 25.00 \\
D & $41-50$ & 11 & 18.33 \\
E & Above 50 & 7 & 11.67 \\
\hline
\end{tabular}

\section{Methods:}

The $10 \%$ formol saline fixed specimens were initially washed with the free-flowing tap water to wash away the formol saline. Then the specimens were taken in metallic tray and the surrounding fat and other unwanted tissues were removed carefully to expose vermiform appendix and its associated structures.

\section{Parameter studied \\ Distance between the base of the appendix and ileocecal junction.}

Procedure for measurement of distance between the base of appendix and ileocecal junction (in cm)

Before measuring the distance between the base of appendix to ileocaecal junction, fixing of the terminal part of the ileum where it ends in the caecum was done by tying the mentioned part of the ileum with thread.

Then the distance was measured by measuring tape graduated in centimeter between the lower border of the terminal part of the ileum to the base of the appendix where taenia coli ends. The average distance for each group was calculated by simple arithmetic mean.

\section{Result:}

Distance between the base of the appendix and ileocaecal junction

Table-II and Fig. 1 showed that the mean distance between the base of the appendix and ileocaecal junction were $22.30 \pm 2.21 \mathrm{~mm}$ in group A (0-20 years), $23.41 \pm 1.62 \mathrm{~mm}$ in group $B(21-30$ years), $23.27 \pm 2.05 \mathrm{~mm}$ in group C (31-40 years),
$23.64 \pm 2.29 \mathrm{~mm}$ in group $\mathrm{D}(41-50$ years $)$ and $23.86 \pm 1.57 \mathrm{~mm}$ in group $\mathrm{E}$ (above 50 years).

The distance between the base of appendix and ileocaecal junction were not significant when compared among different age groups $(\mathrm{P}>0.10$ or $\mathrm{P}>0.50)$.

\section{Table-II}

Distance between the base of appendix and ileocaecal junction in different study groups

\begin{tabular}{|c|c|c|}
\hline Groups & $\mathrm{n}$ & $\begin{array}{c}\text { Length in } \mathrm{cm} \\
\text { Mean } \pm \mathrm{SD}\end{array}$ \\
\hline \multirow[t]{2}{*}{$\bar{A}$} & \multirow{2}{*}{\multicolumn{2}{|c|}{10}} \\
\hline & & $(18.00-26.00)$ \\
\hline \multirow[t]{2}{*}{ B } & \multirow{2}{*}{\multicolumn{2}{|c|}{17}} \\
\hline & & $(21.00-26.00)$ \\
\hline \multirow[t]{2}{*}{ C } & \multirow{2}{*}{\multicolumn{2}{|c|}{15}} \\
\hline & & $(20.00-26.00)$ \\
\hline \multirow[t]{2}{*}{ D } & \multirow{2}{*}{\multicolumn{2}{|c|}{11}} \\
\hline & & $(20.00-29.00)$ \\
\hline \multirow[t]{3}{*}{$E$} & \multirow[t]{3}{*}{7} & $23.86 \pm 1.57$ \\
\hline & & $(22.00-27.00)$ \\
\hline & & Length \\
\hline \multicolumn{2}{|l|}{ Groups } & $P$ values \\
\hline \multicolumn{2}{|l|}{$A$ vs B } & $>0.10^{\mathrm{ns}}$ \\
\hline \multicolumn{2}{|l|}{ A vs C } & $>0.10^{\mathrm{ns}}$ \\
\hline \multicolumn{2}{|l|}{ A vs $D$} & $>0.10^{\text {ns }}$ \\
\hline \multicolumn{2}{|l|}{ AvsE } & $<0.10^{\text {ns }}$ \\
\hline \multicolumn{2}{|l|}{$B$ vs $C$} & $>0.50^{\mathrm{ns}}$ \\
\hline \multicolumn{2}{|l|}{$B$ vs D } & $>0.50^{\mathrm{ns}}$ \\
\hline \multicolumn{2}{|l|}{ B vs $E$} & $>0.50^{\mathrm{ns}}$ \\
\hline \multicolumn{2}{|l|}{ C vs D } & $>0.50^{\mathrm{ns}}$ \\
\hline \multicolumn{2}{|l|}{ C vs E } & $>0.50^{\text {ns }}$ \\
\hline \multicolumn{2}{|l|}{ D vs $E$} & $>0.50^{\mathrm{ns}}$ \\
\hline \multicolumn{2}{|l|}{ Group A } & Age $0-20$ years \\
\hline \multicolumn{2}{|l|}{ Group B } & Age 21 - 30 years \\
\hline \multicolumn{2}{|l|}{ Group C } & Age 31 - 40 years \\
\hline Group D & & Age 41 - 50 years \\
\hline Group E & & Age above 50 years \\
\hline \multicolumn{3}{|c|}{$\begin{array}{l}\text { Figures in parentheses indicate range. Statistical } \\
\text { analysis was done by ANOVA (multiple comparison), } \\
\mathrm{ns}=\text { not significant }\end{array}$} \\
\hline
\end{tabular}




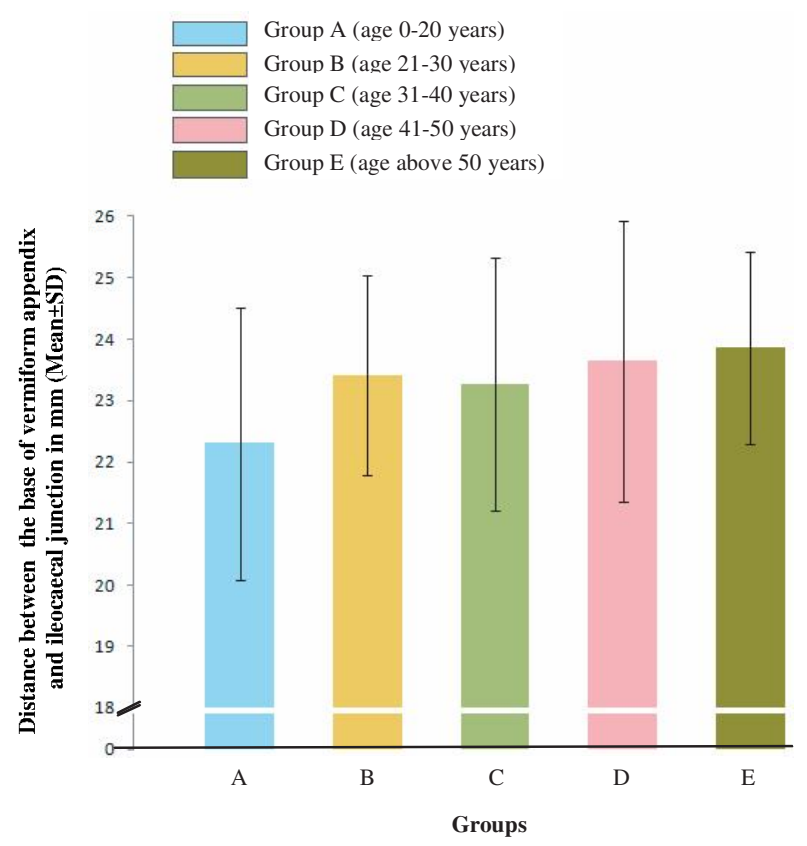

Fig.-1: Distance between the base of vermiform appendix and ileocaecal junction in different study groups.

\section{Discussion:}

In the present study, the highest mean distance between the base of the appendix and the ileocaecal junction was found to be $23.86 \pm 1.57 \mathrm{~mm}$ in group $E$ (above 50 years), whereas the lowest mean distance was $22.30 \pm 2.21 \mathrm{~mm}$ in group $\mathrm{A}(0-20$ years $)$.

The distance between the base of the appendix and the ileocaecal junction was not significant among the different age groups. In the present study, the distance between the base of the appendix and ileocaecal junction correlates with the findings of Borley ${ }^{1}$, Ndoye et a ${ }^{3}$.

\section{References:}

1. Borley NR. Vermiform appendix. In: Standring $\mathrm{S}$, Ellis $\mathrm{H}$, Healy JC, Johnson D, Willimas A, Collins P, et al., editors. Gray's anatomy: the anatomical basis of clinical practice. $39^{\text {th }} \mathrm{ed}$. Edinburgh: Elsevier Churchill Livingstone; 2005. p. 1189-90.

2. Moore KL, Dalley AF. Clinically oriented anatomy. $4^{\text {th }}$ ed. Philadelphia: Williams and Wilkins; 1999. p. 350-4.

3. Ndoye JM, Ndiaye A, Ndiyae A, Dia A, Fall B, Diop $\mathrm{M}$, et al. Cadaveric topography and morphometry of the vermiform appendix. Morphologie 2005; 89(285):59-63.

4. Glover JW. The human vermiform appendix. TJ Arch 1988; 3 (1):31-8. 